\title{
Oxytocin versus methyl ergometrine in the management of third stage of labor: a comparative study from a South Indian tertiary care hospital
}

\author{
Deepa Rajendran, Mamatha Shivanagappa*, Anjali Siddesh, Surakshith Gowda
}

\begin{abstract}
Department of Obstetrics and Gynecology, JSS Medical College and Hospital JSS University, Mysore, Karnataka, India
\end{abstract}

Received: 13 April 2016

Accepted: 19 April 2016

\section{*Correspondence:}

Dr. Mamatha Shivanagappa,

E-mail: mamathamahesh106@gmail.com

Copyright: (c) the author(s), publisher and licensee Medip Academy. This is an open-access article distributed under the terms of the Creative Commons Attribution Non-Commercial License, which permits unrestricted non-commercial use, distribution, and reproduction in any medium, provided the original work is properly cited.

\begin{abstract}
Background: Methyl ergometrine is the conventionally used oxytocic. A few studies have shown that oxytocin is also effective in with fewer adverse effects. This study was carried out to compare the efficacy of oxytocin and methergine in the management of third stage of labor.

Methods: 100 pregnant women with gestational age more than 37 weeks were taken up. Excluded were those with polyhydramnios, fibroid complicating pregnancy, intrauterine hemorrhage, antepartum hemorrhage, previous history of postpartum hemorrhage and contraindications to methergine. The subjects were randomised into two groups one given $0.2 \mathrm{mg}$ Methylergometrine and the other 10 Units of Oxytocin. The efficacy and the safety of these two drugs were analyzed with respect to fall in Haemoglobin $(\mathrm{Hb})$ and Haematocrit $(\mathrm{Hct})$ level, need for additional uterotonic agents, need for uterine evacuation, need for blood transfusion and duration of third stage of labor.

Results: The mean duration of third stage of labor in the methergine group was $6.44 \pm 2.426$ min and in the oxytocin group 6.28 $\pm 2.556 \mathrm{~min}$. Mean blood loss was $224.80 \pm 50.759 \mathrm{ml}$ and $237.0 \pm 69.583 \mathrm{ml}$. The mean fall in $\mathrm{Hb}$ was $0.82 \pm 0.29 \%$ and $0.86 \pm 0.007 \%$. The mean fall in PCV was $0.93 \pm 0.65$ and $0.91 \pm 0.64 .6(6 \%)$ in the oxytocin group required additional methergine. $8(16 \%)$ who received methergine had vomiting and $9(19 \%)$ had risen in blood pressure, while those on oxytocin alone did not have any significant adverse effects. Methylergometrine and Oxytocin were equally efficacious in reducing blood loss and duration of third stage of labor.

Conclusions: Intramuscular oxytocin is equally effective but has a better safety profile compared to methyl ergometrine and hence is a more preferable prophylactic uterotonic management of the third stage of labor.
\end{abstract}

Keywords: Oxytocics, Postpartum hemorrhage, Atonic uterus, Pregnancy

\section{INTRODUCTION}

Postpartum hemorrhage (PPH) is the leading cause of maternal death globally. ${ }^{1}$ According to World Health Organization estimates worldwide about 20 million maternal morbidities are due to haemorrhage and nearly 51,500 maternal deaths occur yearly because of postpartum hemorrhage. ${ }^{2,3}$ India has dubious distinction of having the highest annual maternal deaths of around 60,000 amounting to $25 \%$ of all maternal deaths worldwide. ${ }^{4}$ Even a small loss of blood can be of great significance in anaemic patients. Any attempt at reducing the incidence of PPH remains a challenge. ${ }^{5}$
Active management of third stage of labour, including early cord clamping and controlled cord traction and administration of oxytocic drugs such as ergometrine and oxytocin have been beneficial. ${ }^{5}$ Methyl ergometrine is a conventional oxytocic used extensively but is associated with unpleasant side effects such as hypertension. Currently there has been increased preference for intravenous oxytocin used alone which has been found effective with fewer side effects.

There are only a few large studies in this regard from South India. Hence the present study was taken up. 


\section{METHODS}

The was a prospective hospital based comparative study conducted in the department of Obstetrics and Gynaecology at JSS Medical College and Hospital, Mysore between December 2012 to June 2014. 100 patients were included. Inclusion criteria was singleton pregnancy and gestational age more than 37 weeks Exclusion criteria were multifetal gestation, polyhydramnios, fibroid complicating pregnancy, intrauterine fetal demise, antepartum hemorrhage, previous history of postpartum hemorrhage, all pregnant women in whom methergine was contraindicated such as those with hypertensive, cardiac and coagulation disorders.

The women were managed actively by 10 Units oxytocin intramuscularly and $0.2 \mathrm{mg}$ methergine intramuscularly immediately after the delivery of the baby. The cord was clamped and cut immediately after the delivery of the baby. Controlled cord traction of the umbilical cord was done.

The following observations were noted (i) Blood loss estimated by blood collecting bag, (ii) Maternal Hemoglobin $(\mathrm{Hb} \%)$ and (iii) Packed cell volume (PCV) before delivery and $24 \mathrm{hrs}$ after delivery, (iv) duration of third stage of labor, (v) need for additional oxytocics, (vi) need for manual removal of placenta or subsequent surgical evacuation of retained products, (vii) need for blood transfusion and (viii) adverse effects of the oxytocics used.

The study was presented before and was cleared by the Institutional Ethical Committee of JSS Medical College.

\section{RESULTS}

Table 1: Distribution according to maternal age, mode of delivery \& oxytocic used.

\begin{tabular}{|lll|}
\hline Age & Frequency & Percentage \\
\hline$<20$ & 24 & 24 \\
\hline $21-25$ & 45 & 45 \\
\hline $26-30$ & 29 & 29 \\
\hline 31 and above & 2 & 2 \\
\hline Mode of delivery & & \\
\hline FTND & 70 & 70.0 \\
\hline LSCS & 30 & 30.0 \\
\hline Total & 100 & 100.0 \\
\hline Oxytocic used & & \\
\hline Methergine & 50 & 50.0 \\
\hline Oxytocin & 50 & 50.0 \\
\hline Total & 100 & 100.0 \\
\hline
\end{tabular}

The total number of cases studied was 100.Age ranged from 18 -32 years. Out of the 100 subjects 45 (45\%) were in the age group of 20-24 years. Out of the 100 women, 70 deliveries were Full term normal delivery and 30 were
Lower Segment Caesarean Sections. 50 women were given oxytocin and 50 women were given Methergine (Table 1).

The Mean duration of third stage of labour among the Methergine group was $6.44 \pm 2.426$ minutes and the mean duration in the oxytocin group is $6.28 \pm 2.556$ minutes. Comparison between the blood losses in the third stage of labour between the two groups is shown (Table 2). The mean $\mathrm{Hb} \%$ in the methergine group was $10.712 \pm 1.1940$ and the mean $\mathrm{Hb} \%$ in the oxytocin group was $11.004 \pm$ 1.1533. The mean $\mathrm{Hb} \%$ 24hrs after delivery in the methergine group is $9.8840 \pm 0.9630 \%$ and in the oxytocin group is $10.1426 \pm 1.08675 \%$ (Table 3 ).

Table 2: Comparison between the duration of labour \& blood loss.

\begin{tabular}{|lllll|}
\hline Variable & Group & Mean & $\begin{array}{l}\text { Std. } \\
\text { deviation }\end{array}$ & P \\
\hline $\begin{array}{l}\text { Duration } \\
\text { of 3rd } \\
\text { stage } \\
\text { (mins) }\end{array}$ & Methergine & 6.44 & 2.426 & \\
\cline { 2 - 4 } & Oxytocin & 6.28 & 2.556 & \multirow{2}{*}{0.749} \\
\hline $\begin{array}{l}\text { Blood } \\
\text { loss }(\mathrm{ml})\end{array}$ & Methergine & 224.80 & 50.759 & \multirow{2}{*}{0.319} \\
\cline { 2 - 4 } & Oxytocin & 237.00 & 69.583 & \\
\hline
\end{tabular}

Table 3: Mean Hemoglobin before \& $24 \mathrm{hrs}$ after delivery.

\begin{tabular}{|llcll|}
\hline Variable & Group & Mean & $\begin{array}{l}\text { Std. } \\
\text { deviation }\end{array}$ & P \\
\hline Hb BD & Methergin & 10.712 & 1.1940 & \multirow{2}{*}{0.217} \\
\cline { 2 - 4 } & Oxytocin & 11.004 & 1.1533 & \\
\hline $\begin{array}{l}\text { HB } \\
\begin{array}{l}\text { 24hrs } \\
\text { later }\end{array}\end{array}$ & Methergin & 9.8840 & 0.96306 & \multirow{2}{*}{0.211} \\
\cline { 2 - 4 } & Oxytocin & 10.1426 & 1.08675 & \\
\hline
\end{tabular}

Table 4: Mean PCV before \& 24hrs after delivery.

\begin{tabular}{|lllll|}
\hline Variable & Group & Mean & $\begin{array}{l}\text { Std. } \\
\text { deviation }\end{array}$ & P \\
\hline PCV & Methergin & 30.306 & 2.2223 & \multirow{2}{*}{0.248} \\
\cline { 2 - 4 } BD & Oxytocin & 30.784 & 1.8785 & \\
\hline $\begin{array}{l}\text { PCV 24 } \\
\text { hrs later }\end{array}$ & Methergine & 29.374 & 2.1144 & \multirow{2}{*}{0.209} \\
\cline { 2 - 5 } & Oxytocin & 29.872 & 1.8132 & \\
\hline
\end{tabular}

The mean PCV in the methergine group was $30.306 \pm 2.2223$ and the mean PCV in the oxytocin group was $30.784 \pm 1.8785$. The mean PCV $24 \mathrm{hrs}$ after delivery in the methergine group was $29.374 \pm 2.1144$ and the mean PCV $24 \mathrm{hrs}$ after delivery in the oxytocin group was $29.872 \pm 1.8132$ (Table 4).

Out of 100 cases in the study $6(6 \%)$ women needed additional oxytocic in the form of IM methergine $0.2 \mathrm{mg}$. The remaining $94(94 \%)$ did not need any additional oxytocic. 
Table 5: Mean duration of 3rd stage of labour (min).

\begin{tabular}{|lllll|}
\hline $\begin{array}{l}\text { Duration } \\
\text { of 3rd } \\
\text { stage }\end{array}$ & Group & Mean & $\begin{array}{l}\text { Std. } \\
\text { deviation }\end{array}$ & P \\
\hline $\begin{array}{l}\text { Vandana } \\
\text { et al }\end{array}$ & Methergine & 3.79 & 1.58 & \multirow{2}{*}{0.2455} \\
\cline { 2 - 4 } $\begin{array}{l}\text { Present } \\
\text { study }\end{array}$ & Oxytocin & 4.42 & 1.96 & 0.749 \\
\hline & Oxythergine & 6.44 & 2.426 & 0.76 \\
\hline
\end{tabular}

Table 6: Distribution of blood loss in the third stage $(\mathrm{ml})$.

\begin{tabular}{|lllll|}
\hline Blood & Group & Mean & $\begin{array}{l}\text { Std. } \\
\text { deviation }\end{array}$ & P \\
\hline $\begin{array}{l}\text { Vandana } \\
\text { Val al }\end{array}$ & Methergine & 156.72 & 82.98 & \multirow{2}{*}{0.66} \\
\cline { 2 - 4 } $\begin{array}{llll}\text { Present } \\
\text { study }\end{array}$ & Oxytocin & 166.64 & 64.17 & \\
\cline { 2 - 4 } & Oxythergine & 224.80 & 50.759 & 0.319 \\
\hline
\end{tabular}

\section{DISCUSSION}

Without proper management Post-Partum Hemorrhage can rapidly progress to cause life threatening blood loss. Because of this unpredictability it does often pose a challenge. Routine practice of active management of third stage of labour has been shown to dramatically reduced hemorrhage by upto $60 \%$. This is a particular benefit in setting where provisions of such maternal health services are inadequate. ${ }^{6}$

Recent studies show that there are still wide variations in practice around the world in the management of third stage of labour. Methyl ergometrine is the conventional oxytocic used extensively but is associated with unpleasant adverse effects such hypertension. Intramuscular oxytocin used alone has been found effective in preventing postpartum hemorrhage and results in fewer side effects and is recommended by World Health Organization. ${ }^{7}$

Misoprostol, a synthetic analogue of Prostaglandin $E_{1}$ has been extensively studied for the prevention of postpartum hemorrhage administered by oral or rectal route. ${ }^{8}$ It has not been found to be as effective as conventional injectable uterotonics and is associated with side effects like shivering and fever. However the problem of lesser efficacy of Misoprostol compared with injectable uterotonics could be solved by alternative routes of administration such as sublingual or oral solution, which result in earlier peak plasma levels of the drug. ${ }^{9}$

In the present study the mean maternal age group was 23.5 years and the study population included women with age ranging from 18-32 years (Table 1). In the study by Vandana Satwe et al the mean maternal age group was 23.3 years. The study included the women with ages ranging from 18-32 years. ${ }^{9}$ The majority of women were Multigravida.Primigravida - 48\% Multigravida - 52\%.
In the present study the mean duration of third stage of labour in the methergine group was $6.44 \mathrm{~min} \pm 2.426$ and in the oxytocin group is $6.28 \pm 2.556 \mathrm{~min}$. The $\mathrm{p}$ value was 0.74 which is statistically not significant. In the study conducted by Vandana, et al the mean duration of third stage of labour in the methergine group was 3.79 min and in the oxytocin group were 4.42 . The $\mathrm{p}$ value was 0.24 which was statistically insignificant (Table 5). ${ }^{3}$ Therefore oxytocin and methergine is effective in reducing the duration of third stage when used intramuscularly. In our study there were no cases with prolonged third stage.

In the study conducted by Vandana et al the mean blood loss was $156.72 \pm 82.98 \mathrm{ml}$ in the methergine group and $166.64 \pm 64.17 \mathrm{ml}$ in the oxytocin group. The $\mathrm{p}$ value was 0.66 and statistically insignificant. ${ }^{9}$ In the present study the mean blood loss in the third stage of labour was $224.80 \pm 50.759 \mathrm{ml}$ in the methergine group and $237.0 \pm 69.583 \mathrm{ml}$ in the oxytocin group. The $\mathrm{p}$ value was 0.3 which is statistically insignificant. The difference in the blood loss between the two studies in the methegine group is $68.08 \mathrm{ml}$ and in the oxytocin group is $70.36 \mathrm{ml}$, therefore in our study the mean blood loss in third stage is significantly low (Table 6).

In a study conducted by Adhikari $\mathrm{S}$ et al there was no statistical significance between the mean fall in $\mathrm{Hb}$ between the methergine group and the oxytocin group. ${ }^{4}$ In the present study, the mean fall in $\mathrm{Hb}$ in the methergine group was $0.82 \pm 0.29 \%$ and in the oxytocin group it was $0.86 \pm 0.07 \%$. The $\mathrm{p}$ value is 0.21 , statistically insignificant. Therefore the decrease in haemoglobin level is slightly less when oxytocin is used intramuscularly compared to when methergine is used.

In the study by Adhikari S, et al there was no statistical significance between the mean fall in PCV between the methergine group and the oxytocin group. ${ }^{4}$ In the present study the mean fall in PCV in the two groups was $0.93 \pm 0.65$ in the methergine group and $0.91 \pm 0.64$ in the oxytocin group with a $\mathrm{p}$ value of 0.2 which is statistically insignificant.

In the study conducted by Adhikari S, et al the incidence of use of additional oxytocics was almost the same though statistically insignificant. The incidence of PPH was higher in oxytocin group compared to methylergometrine group but this did not reach statistical significance. ${ }^{4}$

In the present study only $6(12 \%)$ women of the oxytocin group required the use of additional oxytocics in the form of IM methergine and none of the women of either groups required exploration of the uterus or blood transfusion. In the study by Adhikari S, et al the adverse effects of oxytocis were mild and they subsided spontaneously. 
In our study $8(16 \%)$ women who received methergine had vomiting and $9(18 \%)$ had risen in blood pressure, while those who were given oxytocin alone did not have any significant side effect. The usage of oxytocin in active management of third stage of labour is beneficial in reducing the blood loss in third stage and thus helps in preventing postpartum haemorrhage. Oxytocin given at dose 10 units intramuscularly is technically easier to use and can be used in situations where intravenous access is unavailable. Oxytocin is very safe to use with least adverse effects and can be used even in high risk women. It can be used even in hypertensive women and in those with cardiovascular disease.

The limitation of our study is the small sample size and further studies with larger number of subjects are needed.

In Summary, it is seen that IM Injection oxytocin is as effective as IM Injection methergine in reducing the incidence of post-partum hemorrhage, strongly favouring its routine use as oxytocic for active management of third stage of labour avoiding the undesirable side effects of nausea vomiting and elevated blood pressure associated with methergine.

\section{CONCLUSIONS}

This study has shown that both methylergometrine and oxytocin were equally efficacious. However Oxytocin had other advantages in the form of ease of administration, significantly better safety profile and lesser contraindications for usage. It is concluded that intramuscular oxytocin is a more preferable prophylactic uterotonic in the active management of the third stage of labour.

\section{ACKNOWLEDGEMENTS}

We thank Dr. Lancy D'Souza Professor of Psychology, University of Mysore, for the Statistical Analysis. Grateful thanks to Ms. Madhumitha. M, Second Year MBBS student JSS Medical College Mysore who provided help in manuscript preparation and proof reading.
Funding: No funding sources

Conflict of interest: None declared

Ethical approval: This study was approved by the Institutional Ethical Committee of JSS Medical College. Mysore

\section{REFERENCES}

1. Abou ZC, Wardlaw T. Maternal mortality in 2000: Estimates developed by WHO, UNICEF andUNFPA. Geneva: World Health Organization. 2000.

2. WHO. Global estimates of maternal mortality for 1995: Results of an in-depth review analysis and estimation strategy. Geneva: WHO. 2001.

3. Dildy GA. Postpartum hemorrhage new management option. Clin Obstet Gynecol. 2002;45(2):330-44.

4. Adhikari S. Rana A. Brita K. Active Management of third stage of labour: comparison between prophylactic intramuscular methylergometrine and intramuscular oxytocin. N.J. Obstet. Gynecol. 2007;2(2):24-6.

5. Finanga M, Kitua A, Nagdaya E, Kimaro G, Mtandu R, Massawe S. (MUCHS) project report: ActiveManagement of third stage of labor, Tanzania Version. 2006.

6. Mudaliar AL Causation and stages of labour. In: Mudaliar and Menon's Clinical Obstetrics, Editors Gopalan S, Rathnakumar S, Jain V. 12th Edition. Hyderabad Universities Press (India) Pvt Ltd: 2015:94-6.

7. Choy CHY, Lau WC, Tam WH, Yuen PM. Randomized controlled trial of intramuscular syntometrin and intravenous oxytocin in management of the third stage of labour. Int $\mathrm{J}$ of Obstet Gynaecol. 2002;109:173-7.

8. Bulgalho A, Daniel A, Faundes A, Cunha M. Misoprostol for prevention of PPH. Int J of Gynaecol Obstet. 2001;73:1-6.

9. Vimala N, Mittal S, Kumar S, Dadhwal V, Mehta S. Sublingual misoprostol verses intravenous methyl ergometrine for active management of the third stage of labour. Int J Gynaecol Obstet. 2004:87(1):1-5.

Cite this article as: Rajendran D, Mamatha $S$, Siddesh A, Gowda S. Oxytocin versus methyl ergometrine in the management of third stage of labor: a comparative study from a South Indian tertiary care hospital. Int J Reprod Contracept Obstet Gynecol 2016;5:1327-30. 